\title{
THE WAR IN THE ORIENT IN THE LIGHT OF INTERNATIONAL LAW.
}

\section{PART II.}

From the Siberian seaport of Vladivostok the Russian cruiser squadron frequently sallied during the earlier part of the war, and did considerable damage to the

Problems of Marting:

Warfare Af.

fecting the

Belligerents

merely. shipping of Japan and of neutral nations as well. Thus, between February and May, rgo4, were sunk the Nakonoura Maru, Gozo Maru and Kinshiu Maru. The first two vessels were

The question at once presents itself as to the right of the Russians to dispense with the adjudication of a Prize Court as to the character of the cargoes carried by the captured ships, and to sink them out of hand. Wheaton says : "If the vessel belong to the enemy, and the captor has no means of retaining possession of her, or of bringing her into port, he is then justified in destroying her, but it is his duty to preserve her papers and as much of her cargo as he can secure." "r And a little later the following interesting passage occurs anent the same subject: " During the Russo-Turkish war of 1877 the former power (Russia) was alleged to have made a practice of sending out fast steamers from Odessa, which, while they avoided the Turkish cruisers, captured Turkish merchantmen, burnt them on the spot, and then set the crews adrift in boats. If this was true, it was an undeniable violation of international law." 48

One naturally wonders whether Russia has been pursuing tactics of this kind in the present war? It seems established, however, that the ships in question were sunk off the coast

The Annual Register, I904, page 376; War and Neutrality in The Far East, by T. J. Iawrence, M.A., L.L.D., page 40.

"Wheaton, (4th English ed.) page 506.

- Wheaton, page 507, where the following references are cited for the statements made; Parl. Papers, Turkey (No. 1), 1878, page 313; and The Times, I5 Dec., 1877.

738 
of Korea at times when their captors.were in imminent danger of destruction at the hands of a superior Japanese naval force. They had no time to take the vessels to port, nor could they spare prize crews to man them. The additional and distressing fact in the case of the Kinshiu Maru that a large number of the brave troops she was transporting sank with her, can hardly be made the basis of a charge against Russia, it being clear that ample opportunity to surrender was given them, and that their refusal was wilful and apparently because of a foolishly sentimental bravery.

Wher war is declared between two states there are sure to be citizens of each in the territory of the other, and ships belonging to either party in the ports of the

Problems of Minritione Wartare Atecting Betilerents and Noutrals enemy. In the good old days the custom was for a state which contemplated war with another to levy an embargo upon all of its adversary's shipping, which happened to be in port before the declaration of war, and when that took place to gather in a rich haul of valuable prizes."

To-day, however, the necessities of commerce exercise a dominating influence over warfare, and such things are managed very differently. Belligerent nations are expected to give each other's ships a reasonable time to leave port after war is declared. This period for departure is commonly known. as "Days of Grace." so In this instance the Japanese by an Imperial decree issued February 9, I904, gave Russian shipping until February 16 to clear from Japanese ports, and granted protection also to Russian ships sailing before that date direct for Japan. Such ships were given permission to discharge cargo and return by a specified route. ${ }^{51}$ These regulations could hardly be considered liberal in comparison with similar rules laid down in other recent wars; but the privileges granted by Russia were even more restricted.

- "War and Neutrality," Lawrence, page 49.

- War and Neutrality, Lawrence, Page 45. For liberal rules made by U. S. during the war with Spain, see Eaton's International Law, page 66 .

"See The Japanese Imperial Decree of February 9th, 1904. 
Japanese merchantmen in Russian ports at the time war was declared (February Io) were permitted to stay " for such period as may be necessary in proportion to their loading requirements, but which shall in no case exceed fortyeight hours, counting from the moment that the present "declaration is published by the local authorities." 82

It may be said in passing that the regulations respecting the citizens of either belligerent residing in the territory of the other were quite drastic. The Japanese permitted residence under certain conditions, but the Russians expelled the Japanese from Manchuria without a day's notice, thus entailing great suffering upon thousands of innocent and unoffending people. ${ }^{\text {ss }}$

The result of the foregoing facts is simply this: A belligerent nation may act with great severity towards the commerce and non-military population of its enemy which chance puts in its power at the beginning of a war, without breaking any rule of international law. The old theory which we have never entirely got away from was that everything belonging to the enemy which cotld be captured under such conditions was fair spoil..$^{\text {st }}$

To-day, however, two powerful factors militate against adherence to even a modified form of the old theory, namely, humanity and commercial interest. It touches our hearts to see such a sight as the flight of the Japanese refugees from Port Arthur, and it touches our pocket-books to have a belligerent merchantman, in whose cargo we are interested, captured in the enemy's port before war has fairly begun.

For these difficulties it seems well to apply the remedy suggested in other matters. Let the whole question of "Days of Grace" be settled by the next Hague Conference. It is of too much importance to neutral states to permit the continuance of the present methods of determination. It should not be left to the discretion of the belligerents, but

\footnotetext{
- See Art. 2nd, of Rules, which the Imperial Government will enforce during the War with Japan.

- War and Neutrality, Lawrence, page 38.

" Hall's International Law, pages 39r-395.
} 
should be fixed for all through an universal agreement by all. Only in this way can the influence of malice and greed be eliminated, and fair and equable rules be obtained.

It has been a long time since there have been so many apparently flagrant breaches of the neutrality of harbors belonging to non-belligerents as have occurred in Naval Opera- the late conflict. This, of course, was largely tions in Neut
tral Harbors far too weak to maintain perfect neutrality, and the belligerents fell into the habit of treating their territory as personal property.

To turn to a case in point: On the day the war began (February 8, I904) a Japanese fleet under Admiral Uriu steamed into the harbor of Chemulpo, Korea, where the Russian cruiser Variag and her consort, the gunboat Korietz, were anchored. The Japanese commander at once informed the Russians that they must leave the harbor at once and fight at sea, or he would attack them within the port. ${ }^{55}$

Then occurred what has since achieved considerable notoriety, namely, "The Protest of the Three Captains."

It happened that at this time the following men-of-war were also in Chemulpo harbor, the Talbot (British), Vicksburg (American), Pascal (French), and Elba (Italian). The captains of all these ships, except the Vicksburg, joined in the following communication, which was sent to Admiral Uriu as soon as his position was made known:

"We consider that, in accordance with the recognized rules of international law, the port of Chemulpo being a neutral port, no country has the right to attack the vessels of another power lying in that port, and that the power which contravenes those laws is solely responsible for any loss of life or damage to property in such a port. We accordingly protest energetically against such a violation of neutrality, and we shall be happy to learn your decision on the subject." se

s The Annual Register, 1904, page 375.

s International Law, as Interpreted During the Russo-Japanese War, by F. E. Smith and N. W. Sibley, page II4. 
This protest, while vigorous, was ineffectual. The Russian ships were forced out on the 9 th, and after fighting gamely for over an hour against a greatly superior force they returned to port badly damaged by shell fire and crowded with wounded and dying.

Assistance was immediately given to them by all of the foreign war vessels in the harbor, who took off their crews, including those who were wounded and those who were not. Subsequently the Russians returned in rowboats belonging to the neutrals and set fire to and blew up their own ships. A demand made by the Japanese Admiral for the men so rescued was refused by the neutral commanders, and eventually the survivors of the Russian crews were put ashore in Russian territory outside the zone of hostilities.

Now three questions are presented by the events just narrated, namely:

Did the Japanese violate the neutrality of Korea?

Was the protest of the captains justified?

Did the foreign commanders exceed their rights as neutrals in rescuing and liberating the Russian crews?

These questions may be answered categorically. It is quite clear that Japan ignored the neutrality of Korea in forcing the Russian ships from the harbor by means of threats, and her defence is the same she has used so often during the present struggle, that Korea was not an independent neutral power, but in fact nothing more or less than territory in dispute between the belligerents subject to an ineffective and fictional government. As has been previously observed there is much truth in such statements, but Japan is estopped from alleging them by the very fact that part of her casus belli was Russia's refusal to guarantee the territorial integrity of China and Korea. To admit her defence in this instance is to deny her sincerity in taking up arms.

With regard to the captains' protest it is hard to see upon what legal principle it was based, though it is easily explainable upon motives of humanity. The only parties involved in the threatened breach of neutrality were the belligerents and the nation of Korea. The interests of the captains' 
countries were in no way affected, and it would seem that they had no more right to intervene than a stranger to a contract in a suit between the promisor and promisee.

The third question is especially interesting because it raises a point which was considered with unusual care, but without definite result by The Hague Conference; that is to say, the responsibility of neutral rescuers of disabled belligerents.

This problem was not definitely solved, the nearest the Conference came to doing so was in "Article 6" of "The Convention for the Adaptation to Maritime Warfare of the Principles of the Geneva Convention of August 22, 1864," which reads as follows:

"Neutral merchantmen, yachts, or vessels having or taking on board sick, wounded, or shipwrecked of the belligerents, cannot be captured for so doing, but they shall be liable to capture for any violation of neutrality which they may have committed." 57

The following additional articles were proposed to the Conference by Captain Mahan of the United States delegation, but they failed of adoption; in fact, Captain Mahan withdrew them:

"I. In the case of neutral vessels of any kind, hospital ships, or others, being on the scene of a naval engagement, which may as an act of humanity save men in peril from drowning from the results of the engagement, such neutral vessels shall not be considered as having violated their neutrality by that fact alone. They will, however, in so doing, act at their own risk and peril.

"2. Men thus rescued shall not be considered under the cover of a neutral flag, in case a demand for their surrender is made by a ship of war of either belligerent. They are open thus to capture or recapture. If such demand is made, the men so rescued must be given up, and shall then have the same status as if they had not been under a neutral flag.

${ }^{8 t}$ The Peace Conference, at The Hague, Holls, page 126. 
" 3 . In case no such demand is made by a belligerent ship, the men so rescued having been delivered from the consequences of the fight by neutral interposition, are to be considered hors de combat, not to serve for the rest of the war unless duly exchanged. The contracting governments engage to prevent, as far as possible, such persons from serving until discharged." s8

It is easily seen that these articles reduce the act of rescue to an orderly scheme, and while they render the rescued liable to become prisoners of war upon demand, they give them a good chance of escape under conditions which prevent their continuing as a menace to the belligerent which has disabled them.

It certainly seems that the foreign captains at Chemulpo rendered more assistance to the Russians than their status as neutrals permitted, but on the other hand, the lack of definite international regulations covering their actions was unquestionably the reason why they pursued the course above mentioned.

The next Conference should decide definitely how far a neutral may go in succoring a belligerent, and what the neutral's responsibility is to the other belligerent for preventing the return of those rescued to their nation's military strength. It is hardly fair that when one belligerent disables the fighting units of its adversary, they should return to the fray as the direct result of the intervention of a neutral power, and it matters not that such intervention is inspired by humane motives. $^{58}$

During the night of August I Ith and I2th, 1904, occurred, what has been termed, the "cutting out " by the Japanese of the Russian torpedo-boat Reshitelni. This vessel, under the command of Lieutenant Rostachakovski of the Russian Navy, had been sent from Port Arthur with dispatches, and reaching the Chinese port of Chefoo on August I Ith, she had

\footnotetext{
1s The Peace Conference, Holls, page 504.

- In this connection, see Art. $x$ of the Second Convention (In re. Maritime Warfare), agreed to at The Hague Conference, Wheaton, page 477 .
} 
been placed by her commander under the orders of Admiral Sah, the ranking officer of the Chinese Navy at Chefoo. It is alleged, with apparent truth, that she had disarmed and that her engines had been disabled.

Shortly after the arrival of the Reshitelni the Japanese destroyers, Asashio and Kasumi, appeared off the port, and after lying there during the day they entered in the evening, and in spite of the commands and protests of Admiral Sah they boarded the Russian ship, and, after some resistance on the part of her crew and an unsuccessful attempt to blow her up, they gained possession and left the harbor with the Reshitelni in tow. ${ }^{\text {B }}$

Now there is no doubt that the action of Japan in this instance was prima facie a gross breach of China's neutrality. It is hornbook law that warlike operations cannot be carried on within the territorial waters of a neutral power. ${ }^{\text {ax }}$ But just here comes the crux of the case. Japan contends that China was incapable of maintaining her neutrality, and that in order to prevent Russia from using Chinese territory for purposes of recruiting, rest and repair, she was obliged to interfere in a way which was in appearance, though not in fact, contrary to the rules of international law. ${ }^{.2}$ Japan argues that in the case of Chefoo, China had winked for months at Russia's "wireless" station, which we dealt with in a previous article. ${ }^{63}$

On the other hand, it appears that China was never given a chance to enforce her neutral powers towards the Reshitelni. That vessel seems to have endeavored to comply with every rule relating to internment, and if the Japanese commander had any doubts about it, it was obviously his duty to call upon Admiral Sah to enforce the law, rather than to take matters into his own hands and violate the spirit and

\footnotetext{
- International Law, Smith and Sibley, page Ir6 et seq.

Wheaton, page 578 .

"War and Neutrality, Lawrence, chap. x., page 202 et seq. It is interesting to compare the facts in question with our own action in the famous 'Florida case,' as to which, see Wheaton, page 58r.

* American Law Register, vol. 53, No. II, page 695.
} 
letter of one rule in an alleged attempt to uphold another. ${ }^{64}$ Japan should not have assumed China's inability to maintain her neutrality.

Regard it as we may, we can hardly see anything in the facts to make the course of the Japanese anything more or less than a gross bre.sich of the neutrality of China and an illegal injury to both China and Russia. Such being the case, it would seem that China has just and lawful cause on which to base a claim against Japan for infringing her rights as a neutral and sovereign power. ${ }^{65}$

At an early stage of the war Russia found herself in a peculiar and unenviable position with relation to her naval Neval Opera- strength. Thanks to the exertions of Admiral Hios On the
High Seas Togo, the Port Arthur fleet was either sunk, disabled or bottled up in the harbor; while the Vladivostok squadron was too weak to act otherwise than as a raiding force. So much for the ships in the Far East.

In Europe the situation was little better. The Mediterranean fleet under Admiral Wirenius was at Jibuti, French Somaliland; the Baltic fleet had not been concentrated or prepared for its famous globe-encircling cruise; while the warships in the Black Sea were effectually corked up therein by numerous treaty obligations. ${ }^{68}$

To relieve this situation Russia did three things, all of which raised questions in international law.

Admiral Wirenius was ordered home via the Red Sea and the Suez Canal.

Several vessels were sent through the Dardanelles as mer-

*t Eaton's International Law, page 97.

* For an interesting account of this incident, see From Tokio Through Manchuria, by Major Seaman, U. S. A., page I74 et seq. Major Seaman there says: "It is only fair to say that it was the general opinion in Chefoo, as it seems to have been elsewhere in diplomatic circles, that the Japanese had committed a flagrant breach of international law. It was accepted as true, everywhere, that the Russian vessel was disarmed, and had complied absolutely, with international requirements, in cases where a belligerent warship visits a neutral port."

${ }^{\infty}$ War and Neutrality, Lawrence, page II3; International Law, Smith \& Sibley, page 40; The Anntal Register, 1904, page 375 et seq. 
chantmen, and subsequently fitted, armed and commissioned as volunteer cruisers.

Finally, the Baltic fleet was made ready for sea through almost superhuman exertion, and its long journey was only performed by the aid of neutral coal obtained in many ports, just as a telegram can only traverse a continent by means of relay batteries which thickly dot its path.

To return to Admiral Wirenius, his homeward voyage was marked by some very strange conduct on his part. $\mathrm{He}$ did not leave Jibuti until thirty-six hours after he was told to do so. ${ }^{67}$ He then captured three neutral merchantmen laden with coal for Japan while returning through the Red Sea. ${ }^{88}$ But the most serious thing he did from an international standpoint was to use the Gulf of Suez as a cruising ground, where for nearly a week he menaced all neutral shipping approaching the Canal, and, as will readily be seen, his position was of such a commanding nature that the commerce of the. world was at his mercy; it was impossible to escape Wirenius if one desired to traverse the Canal. ${ }^{69}$

Now the convention of $I 888$, which provides for the neutralization of the Suez Canal, reads as follows: "Article I. The Suez Maritime Canal shall always be free and open, in time of war as in time of peace, to every vessel of commerce or war without destinction of flag.

"Consequently, the High Contracting Parties agree not in any way to interfere with the free use of the Canal, in time of. war as in time of peace. The Canal shall never be subjected to the exercise of the right, of blockade.... The High Contracting Parties agree that no right of war, no act of hostility, nor any act having for its object to obstruct the free navigation of the Canal, shall be committed in the Canal and its ports of access, as well as within a radius of three marine miles from those ports." 70

\footnotetext{
"War and Neutrality, Lawrence, page Ir4.

- See note 67.

- Wheaton, page 315 , where the legal status of the canal, is explained and commented on.

${ }_{79}$ Wheaton, Appendix I, page 806.
} 
Thus it is clear that the Russian Admiral violated the spirit, if not the letter, of the law. It is probable that he hovered at a legal distance from the Canal approaches, but still so close that he was in fact maintaining an effective blockade. Obviously it will be necessary in the light of this occurrence for the Powers to increase the extent of the neutral waters adjoining the Canal, or in the next important war we may see more serious results from a similar defiance of international law.

Russia's action regarding the volunteer cruisers recalls some interesting facts of history. Ever sinces the treaty of I 84I the principle of closing the Straits at the entrance of the Black Sea to vessels of war has been maintained by the concert of the Powers. ${ }^{71}$ This principle was confirmed by the treaties of $1856,{ }^{72}$ and subsequently by the London Convention of $1871,{ }^{73}$ and the Eighteenth Protocol of the Treaty of Berlin, which was signed in $1878 .{ }^{74}$

As has been stated, the beginning of this war found Russia with a fleet of warships in the Black Sea, which she was allowed to keep there for police purposes, but with no way of getting them out without contravening the abovementioned treaties.

In this predicament she resorted to deception. Taking three swift auxiliary cruisers, the Smolensk, Petersburg and Sevastopol, the Russians disguised them as merchantmen,

\footnotetext{
${ }^{n}$ International Law, Smith \& Sibley, page 30.

Tz International Law, Smith \& Sibley, page $3 \mathrm{I}$.

${ }^{73}$ International Law, Smith \& Sibley, page 32.

"International Law, Smith \& Sibley, page 33. See also Wheaton, page 226, where the following occurs: "The Treaty of Berlin, contains no express mention of the Dardanelles, but in the Eighteenth Protocol, Lord Salisbury, declared on behalf of England that, 'the obligations of $\mathrm{Her}$ Britannic Majesty, relating to the closing of the Straits, do not go further than an engagement with the Sultan to respect in this matter, His Majesty's indepencient determination in conformity with the spirit of existing treaties.' The Plenipotentiaries of Russia, declared in reply that, 'without being able exactly to appreciate the meaning of Lord Salisbury's proposition,' in their opinion, the principle of the closing of the Straits is an European principle; and that existing stipulations are binding on the part of all the powers, not only as regards the Sultan, but also as regards all the Powers signatory to these transactions.' "
} 
and on July 6th and 7 th, I904, sent them through the Straits. The vessels flew the commercial flag of Russia, and one at least was flying the Red Cross flag and painted white to resemble a hospital ship.

No sooner, however, did these ships reach the open sea than the sunlight glinted upon the shining barrels of their guns, and from peaceful merchantmen they changed in a twinkling into veritable greyhounds of the sea. ${ }^{75}$

A few days after this metamorphosis (July $\mathrm{I} 3^{\text {th }}$ ), the Petersburg seized the British P. and O. steamer Malacca in the Red Sea. Although the Malacca was simply carrying ammunition for an English garrison, the Russians took her to Algiers as a prize, and did not release her until July 28th. ${ }^{76}$

Of course, this incident was entirely irregular in itself, and caused a great outcry in England, and it also directed the attention of the Powers to the status of the captor and her sister ships, and brought up the paramount question of the inviolability of the Straits agreements.

It really seems incontrovertible that the passage of the Straits by the Russian vessels was in contravention of all the treaties bearing upon the matter. The ships were men of war in disguise at the time of the passage. It would seem that Russia might legally have armed and commissioned them at sea had they been bona fide merchantmen to start with, but they were nothing of the kind.

England, indeed, has insisted strenuously that their true status was that of privateers, and hence constituted a violation of the Declaration of Paris. Be that as it may, the lesson which the incident as a whole bears for the world is the importance of providing an adequate method in all cases for enforcing an observance of treaty obligations, and it shows how foolish it is to entrust such enforcement to so vacillating and futile an agency as The Sublime Porte.

The long voyage of the Baltic fleet was chiefly memorable,

"The Annual Register, 1904, page 317.

"International Law, Smith \& Sibley, 4I. 
from a legal standpoint, because it raised questions as to duration of stay in neutral waters, supply of coal by neutrals to belligerents, repairs permissible in neutral ports, and the effectiveness of arbitration.

In dealing with the various ways in which a neutral may legally furnish assistance to a belligerent we are confronted by the fact that there is a great divergence of opinion among the nations with regard to the amount of assistance permissible.

England is the most powerful adherent of the narrow view, while France is the foremost champion of the liberal theory. We shall readily understand the position of Great Britain on such matters if we note the following ingenuous paragraph which recently appeared in an article entitled, " Maritime Responsibilities in Time of War," by Lieutenant Carlyon Bellairs, R. N. ${ }^{77}$ Lieutenant Bellairs says: "It is impossible to understand British views on international law unless we keep ever before us the fact that naval supremacy is the great object of all British policy. In 1904, Britain's naval expenditure, according to a Parlimentary return, was over $\$ 25,000,000$ greater than that of France, Germany and Russia combined. Success is assumed as an axiom; and any law tending to limit the power of the strong navy as opposed to the weak one would be regarded as an abridgment of British sea power. It is true that a war with a European Power may result in stalemate, but she can console herself with her security on the sea where her interests lie; the obvious embarrassments of her opponents' position, and with the philosophical maxim that 'he that endureth to the end shall be saved.' When, in addition, we reflect that Great Britain possesses in her Empire the extensive coastline of 42,900 miles, with a unique series of coaling stations along every trade route in the world, we see at once that she has not nearly the same need as her rivals to secure during war any benevolent neutral assistance."

In accordance with the spirit displayed in the foregoing

"The North American Review, vol. I8r, No. 2, page I68. 
quotation, Great Britain refuses to allow belligerent warships to stay in her ports longer than twenty-four hours, and refuses to sell them more than enough coal to take them to the nearest neutral or national port, and insists furthermore that such coal shall be used only for navigation.

On the other hand, France and countries which like her are not great colonial powers, permit belligerents while in their ports to purchase supplies and make repairs which may be necessary for " the subsistence of the crews and the safety of the navigation." 78 Nor do they insist upon such rigid rules with regard to the length of time a belligerent may stay in their harbors. For instance, Admiral Rojestvensky stayed at Kamranth Bay, French Cochin China, from April I4th to April 22d, I905, and, so it is alleged, coaled and provisioned there. Now the query is pertinent, if there is such a difference in the rules adhered to by various nations, what is really the law?

The answer is that there are only a few fundamental rules of neutral conduct in such matters which may be regarded as binding upon all nations, and that all minor regulations are left to the discretion of the individual powers, with the proviso that no discrimination shall be made as between belligerents.

Hence the policy of neutrals in such matters is entirely governed by their own resources, and a country like England which in time of war needs little or no neutral assistance is sure to frame rules which will reduce such assistance to the minimum, while a country such as France will obviously pursue a contrary policy. It may be said here that the United States seems to have followed England in matters of this kind, although her own position and interest seem to render an adherence to the French theory advisable. ${ }^{79}$

\footnotetext{
"The North American Review, vol. 18r, No. 2, page 176, where, a French view of the subject is presented by $M$. Charles Dupuis.

79 Eaton's International Law, page 98; Article by Hon. Hannis Taylor, The North American Review, vol. I8I, No. 2, page I6r esp., page 165 .
} 
As to the rules which all neutrals must observe they simply provide that there must be no warlike operations in neutral ports, there must be no supplies of arms or munitions of war furnished to belligerents, nor must their forces be recruited upon neutral ground. ${ }^{\circ 0}$

The interesting questions as to the limitation of stay and of supply of coal and provisions are within the discretionary category just mentioned, and are far from settled. The reason given for a strict limitation is, that a liberal ruling results in indirectly assisting one belligerent to war upon another.

The champions of the liberal view say, however, that such assistance is by no means certain to help the belligerent in carrying on the war, but is simply a sale to him of necessities of life, and if equal opportunities are given to each belligerent no injustice is done. ${ }^{81}$

The matter seems very arguable, and it would smack of dogmatism to attempt to decide it.

In the case in point a great deal of assistance was unquestionably given to the Russian fleet, mostly from French sources, and it is seemingly true that without such ex-

* The Principles of International Law, by T. J. Lawrence, page 518 , et seq. See also Eaton's International Law, page 96.

"-In The North American Review, vol. I8I, No. 2, at page 182, M. Dupuis says: "French, as compared with English doctrines, allow neutral States much greater liberty of action. They leave them the option of permitting, or forbidding, certain acts, which the English, are inclined to hold should be necessarily forforbidden. The French custom imposes many less restrictions than the British. *** France, throws her ports wide open to belligrent warships; she does not limit the length of their stay; she only limits it to twenty-four hours, when they have entered the port with prizes taken from the enemy. Warships, which have sought refuge in a neutral port, to escape the enemy's pursuit, are free to stay or to leave. If the enemy wishes to reduce them to a state of impotence, it is for him to take the necessary measures to make it dangerous for them to leave. Belligerent warships which have entered a French port, may effect repairs there, or take in stores necessary for navigation, or for the subsistence of their crews; they may not, on the other hand, recruit combatants, or provide themselves with arms, munitions, or articles for use in action. Their stay in a neutral port, may, therefore, allow them to leave it with fresh means of navigation, but not with any increase of fighting strength." See also Wheaton, page 587. 
traneous aid it would never have been able to complete its long voyage and engage in the terrible battle of the Korean Straits. There is no question that Germany would be guilty of a breach of neutrality, should she allow a Russian army to march across her territory to invade France, and it is a nice problem whether, after all, the French treatment of the Baltic fleet does not differ merely in degree from such conduct.

Brief notice may be taken of the famous "North Sea Incident" which occurred early in the voyage of the ill-starred Baltic fleet. The facts are sufficiently well known, and require little discussion. Some English trawlers in the North Sea were fired upon by the Russians during the night of October 21 st and $22 \mathrm{~d}$, 1904, with the result that several fishermen were killed and wounded, and one vessel wàs sunk. The Russians mistook the fishing boats for Japanese destroyers. $^{82}$

The interest of the incident in international law arises simply from its disposition. Despite a popular outcry in Britain, which a few years ago would have in all probability resulted in immediate war, the government maintained its poise, and the matter was settled by arbitration under the provisions of Articles 9 to 14 of The Hague Convention of $1899^{83}$

The report of the Arbitral Commission provided for proper compensation to the sufferers, and dealt with the offence in diploniatic terms, which, while they did not seem as severe as the occasion required, still had the effect of restoring nearly normal relations between the parties to the controversy.

The incident as a whole may well be regarded as a triumph for the cause of international peace.

There are one or two other matters which may properly be considered under naval operations on the high seas, and

The Annual Register, I904, pages 221 and 316.

- The Law Magazine and Review, vol. xxx, No. 335, page 203; The Hague Conference, Holls, pages 203-220; International Law, Smith \& Sibley, pages 288 and 452. 
foremost among these is the sinking of the British steamer, Knight Commander, by the Vladivostok squadron on July 24th, 1904, off Idzu. The vessel was laden with alleged contraband railroad material, and the Russians claimed that they could not spare a prize crew, were themselves in imminent danger of capture, and had no time to take their prize to port for adjudication. ${ }^{84}$

This occurrence raised the question discussed in the beginning of this article in its most acute form, for here it was a matter not between the belligerents alone, but between a belligerent and a neutral. English authorities have contended that under no circumstances could Russia's action in this case be justified, and such a contention is in line with the British policy above mentioned, for, in case of war, England would never be so far from her own ports as to render a similar act a necessity. However, it seems that if a nation is willing to make ample reparation in case she makes a mistake as to the character of the cargo, destination, etc., there is no valid reason why she should not in extreme cases sink a neutral ship carrying contraband. She has to choose between allowing munitions of war to proceed to her adversary's assistance or running great risk of naving her own ships captured in taking them to port for adjudication. In this dilemma sinking the contraband seems to be the only way of cutting the Gordian knot, and in such a case the neutral nation has no right to take offence, since it is universally acknowledged that ships, carrying contraband, trade at their peril. Of course, wherever possible a prize should be taken to port and given the benefit of a trial, but in a clear case under the above circumstances such action as Russia took seems justifiable.

Several times during the war the belligerents searched the mail steamers of neutral powers, and while these actions seemed generally to be within the right of search enjoyed by

\footnotetext{
* The Annual Register, 1904, pages 175 and 317; International Law, Smith \& Sibley, page 186; The Law Magazine and Review, vol. xxx, No. 334. page 80: Articles of Messrs. Taylor and Bellairs, North American Review, vol. 181; No. 2, pages 168 and 171 .
} 
belligerents upon the high sea, ${ }^{95}$ still it seems well to call attention to the fact that the United States has for years insisted that only in extreme cases is there any justification for interfering with the mails of a neutral power. ${ }^{80}$ This policy is attributable to commercial interest, which demands that a peculiar sanctity shall attach to the mails as the instruments of trade the world over.

There has probably never been a war in which submarine mines played so important a part. Their value as destructive agents was amply demonstrated be-

Marine

Minesfore the conflict was a month old. The sinking Their of such powerful vessels as the Petropavlosk and the Hatsuse with hundreds on board, not to speak of many less serious catastrophes, showed plainly the terrible power of these unseen foes. ${ }^{87}$ But the most serious feature of the situation was in relation to neutral ships.

Unquestionably these mines are legal instruments of warfare so long as they are confined to territorial waters; that is, so long as they are moored within three miles of the shore, but it seems indisputable that in this war mines were employed much farther out. Many were found floating at. large far out in the Gulf of Pechilif, constituting a horrible menace to innocent and unoffending merchantmen. ${ }^{88}$

It is clear, then, that immediate steps should be taken to restrain mining operations in future contests within legal

s In Eaton's International Law, the following appears at page 128: "The right of visiting and searching a merchant ship on the seas, whatever be the ships, whatever be the cargoes, whatever be the destination, is an incontestable right of the lawfully commissioned cruisers of a belligerent nation *** because till they are visited and searched, it does not appear what the ships, or the cargoes, or the destination are, and it is for the purpose of ascertaining these facts that the necessity of this right of visitation and search exists." (Sir W. Scott)

* War and Neutrality, Lawrence, pages 190 and Igr; see also article by Commander von Uslar, North American Review, vol. 181, No. 2, page 186.

Ine Annual Register, 1904, page 376.

- From Tokio Through Manchuria, by Major Seaman, chap. vii.; Among Russian Mines in the Gulf of Pechili, at page ro\%. 
limits. But at this point we encounter a hot discussion as to what those limits should be.

There are many who contend that while three miles was a proper distance fifty years ago, yet to-day it is not far enough because owing to the increased range of modern guns a power holding the shore has gained control over at least four more miles of his sea front than he formerly had. On the other hand, if the limit of territoriality is increased the danger to neutral commerce from mines and torpedoes will be greatly increased with it. The question is a nice one, and very difficult to determine, but it would seem that it would be wise to increase the territorial limits subject to special regulations affecting mines and torpedoes at a certain - distance from shore. ${ }^{89}$

Practically none of the interference with neutral vessels which we have just discussed would have occurred if the guestions as to belligerents had not suspected that the neutrals contrabasd were carrying contraband of war.

The word contraband has a meaning which is peculiar to international law; it signifies articles or goods which are clearly fitted by character or destination, or both, for use in warfare by a belligerent state. The law allows the confiscation of such goods when captured by a belligerent, but it is imperative that their contraband character shall be decided wherever possible by a prize court.

Modern international law has divided contraband into two classes-namely, absolute and conditional. That is to say, articles such as arms, powder, etc., about which there can be no doubt are absolutely contraband, while such a thing as railroad material, for instance, is only considered contraband if its destination and other circumstances show that it was in all probability intended to be used in warfare.

It is customary for each belligerent to state clearly at the beginning of a war exactly what articles it will consider

- North American Review, vol. 181, No. 2, page 184; International Law, Smith \& Sibley, pages 94-97; War and Neutrality, Lawrence, pages 93-111. 
contraband, and this course was followed by both parties to the conflict under discussion.

On February 1oth, 1904, the Japanese Government notified the powers as to the articles it would consider contraband, and this notification recognized the distinction above alluded to between "absolute" and "conditional" contraband.

Absolute contraband was made to include "military weapons, ammunition, explosives, and materials (including lead, saltpetre, sulphur, etc.), and machinery for making them, uniforms, naval and military, military accoutrements, armour-plated machinery, and materials for the construction or equipment of ships of war."

Among goods, conditionally contraband, that is to say, contraband if in all probability destined for military use, were classed "provisions, drinks, horses, harness, fodder, vehicles, coal, timber, coins, gold and silver bullion, and materials for the construction of telegraphs, telephones and railways." $"$

On the other hand, the "Rules which the Imperial Government will enforce during the war with Japan," which were issued by Russia February 28th, I904, made no distinction between absolute and conditional contraband. Furthermore, they included as absolute contraband articles which hitherto had not been regarded among the nations as even conditionally so. The three most offensive clatses of the "Rules" provided that the following should be considered as absolutely contraband:

" 8. Every kind of fuel, such as coal, naphtha, alcohol, and other similar materials.

"9. Articles and material for the installation of telegraphs, telephones or for the construction of railroads.

" Io. Generally, everything intended for warfare by sea or land, as well as rice, provisions, and horses-beasts of burden and others which may be used for a warlike purpose,

- Imperial Decree of Japanese Government, published February roth, 1904 
if they are transported on the account of, or are destined for the enemy." "91

These "Rules" were an entirely new departure in international law, and were met by vigorous protests from the powers, notably Great Britain and the United States.

Secretary Hay, writing to Ambassador McCormick, on August 3oth, 1904, regarding the capture and condemnation of the American steamship Arabia, laden with flour for Japan, thus tersely and forcibly stated the position of our own government: "When war exists between powerful states, it is vital to the legitimate maritime commerce of neutral states that there be no relaxation of the rule-no deviation from the criterion-for determining what constitutes contraband of war, lawfully subject to belligerent capture; namely, warlike nature, use, and destination. Articles which, like arms and ammunition, are by their nature of self-evident warlike use, are contraband of war if destined to enemy territory; but articles which, like coal, cotton and provisions, though of ordinarily innocent, are capable of warlike use, are not subject to capture and confiscation unless shown by evidence to be actually destined for the military or naval forces of a belligerent." 92

Not until September, I904, did Russia recede in any way from her extreme position, and then she only modified it by an order which in effect recognized the status of provisions as conditionally contraband.

Russia's action with regard to coal was absolutely incon-

"See Art vi. of the Rules, which the Imperial Government will enforce during the war with Japan and Appendix II., to section, I4, of the Instructions approved by the Admiralty Council, September 20,1900 .

;z See Letter of Hon. John Hay to Hon. Robert S. McCormick, dated August 30th, 1904; No. 143, Diplomatic correspondence with U. S. Embassy in St. Petersburg. Published by Dept. of State. See also on the general subject Wheaton pages 667-673; International Law, Smith \& Sibley, pages 194-257. Leading cases on International Law, Pitt Cobbett, pages 3II-333; Eaton's International Law, pages 108-116; Lawrence on International Law, pages 598-623. Sir Henry Maine, in his interesting Lectures on International Law says: "From the very beginning of International Law, a belligerent has been allowed to prevent a neutral from supplying his 
sistent with her position at the West African Conference of I884-85, when she refused to admit that it was even conditionally contraband. ${ }^{83}$

By a supplement to the above-quoted rules, raw cotton suitable for the manufacture of explosives, was added to the list without regard to the fact that such cotton is just as suitable for purposes of peaceful manufacture. ${ }^{\text {s }}$

It is true that the fortune of war prevented the Russian "Rules" from creating the international complications which would naturally flow from their enforcement, but nevertheless there is no question but that they constituted in themselves a most serious breach of international law, and it would seem that the powers would be justified in taking all proper steps to avoid the repetition of such a brazen defiance of the most fundamental rules relating to contraband of war.

enemy with things capable of being used immediately in war. Such things are called technically ' contraband of war,' and may be condemned, independently of all question as to the neutrality of the owner. The ship and cargo are taken into a port of the captor; the contraband is condemned in a prize court, but the fate of the ship itself varies. If the ship belongs to the owner of the contraband or if the owner of the ship is privy to the carriage of the contraband, the ship is condemned, but not so, if the ship belongs to a different owner, who knows nothing of the destination of the contraband commodities. This branich of International Law is complex, and difficult, but it owes its intricacy and difficulty to one special question: What, are the articles stigmatized as contraband? From the very first, Grotius, had laid down that, things directly used in war-for example, weapons-were contraband. He had also ruled that things useless in war, articles of luxury, as he described them, were not contraband. But, outside these categories, there were a great number of things capable of employment, both in war and peace-rcs ancipitis usus-and it is in regard to thesc that innumerable questions have arisen. Are articles of naval construction-for example, the raw materials of sails and cordagecontraband? Do they become so at any particular stage of manufacture? Are iron, brass, steel, etc., contraband? Are coals and horses? Are provisions contraband? To these questions, all sorts of answers have been given. In many special treaties, the list of contraband and non-contraband commodities is given, and the practice of States is extremely various. On the whole, the most general rule which can be laid down, is that, with the exception of weapons, or munitions of war, the contraband or noncontraband character of the cargo must depend on its destination, and on the nature of the particular wat which is going on."

"International Law, Iawrence, page 612; British State Papers, Africa No. 4. (1885), pages 132 . I33, $3 \mathrm{II}$.

See Supplement to Russian War Rules, issued April 21st, I904. 
Several such matters have been dealt with under previous Questions of headings, and it is merely necessary to say a interameat word about the Mandjur, and the squadron of Admiral Enquist.

At the outbreak of hostilities the Russian gunboat Mandjur was bottled up in Shanghai harbor by the Japanese cruiser Akitsushima.

China, as she had a right to do, ordered the Mandjur to depart in twenty-four hours, but the big Japanese cruiser was in the offing, so the Russian refused to leave.

This was a breach of international law with regard to China, but, as usual, she was too weak to enforce her neutrality. Japan might have taken this for a pretext to sail in and force a fight, as she did in the case of the Reshitelni. However, she chose a more pacific course, and finally an agreement for the internment of the Mandjur was arrived at between all the parties. Internment, meaning in this, as in all cases, disarming the ship and crew, and keeping them at the place of internment till the end of the war.

The incident was simply another evidence of China's inability to assert her rights as a sovereign power. ${ }^{95}$

The case of Admiral Enquist was peculiar. On June 9th, 1905, he turned up with three cruisers, battered survivors of bloody Tsushima, in Manila harbor, and asked for permission to make repairs and then sail for home.

Permission to do so was denied him, however, on the ground that his injuries had resulted from warfare and not from dangers of the sea. He was warned to leave at once or intern, and chose the latter alternative."

It certainly seems upon authority that the distinction our Government made as to the source of the injuries is a new departure in international law.

The rule hitherto has been that a wounded belligerent ship might make repairs in a neutral port, and was exempt from the usual requirement of departure within twenty-four hours.

\footnotetext{
* War and Neutrality, Lawrence, page 137; Wheaton, page 562, on the subject of Internment.

* North American Review, vol. 181, No. 2, pages 165, 180.
} 
True it is that our new rule may be merely a port regulation, and therefore perfectly legal, for we can make these at will so long as they apply equally to all belligerents. But it is submitted that our action was unwise in view of the fact that we are not a great colonial power like England, and some time we may be confronted with our own "rule" when our ships are seeking asylum in distant seas.

In conclusion, it may be said that the present war has been concusion an inestimable boon to international law, and will in all probability make for general peace.

The question it has raised, some of which we have briefly touched upon, demand adequate solution, and that at no distant day.

A new Hague Conference is an absolute necessity in the light of recent events, and let us hope that success may attend its deliberations, and that it may have the unseen guidance of Him who is not only the God of Battles, but also the God of Love.

Theodore J. Grayson. 